\title{
Discrimination starts at home: A brief on parents' aspirations for adolescents and youth in Pakistan
}

Minhaj ul Haque

Population Council

Follow this and additional works at: https://knowledgecommons.popcouncil.org/departments_sbsr-pgy How does access to this work benefit you? Let us know!

\section{Recommended Citation}

ul Haque, Minhaj. 2005. "Discrimination starts at home: A brief on parents' aspirations for adolescents and youth in Pakistan," brief based on Adolescents and Youth in Pakistan 2001-02: A Nationally Representative Survey. Islamabad: Population Council. 


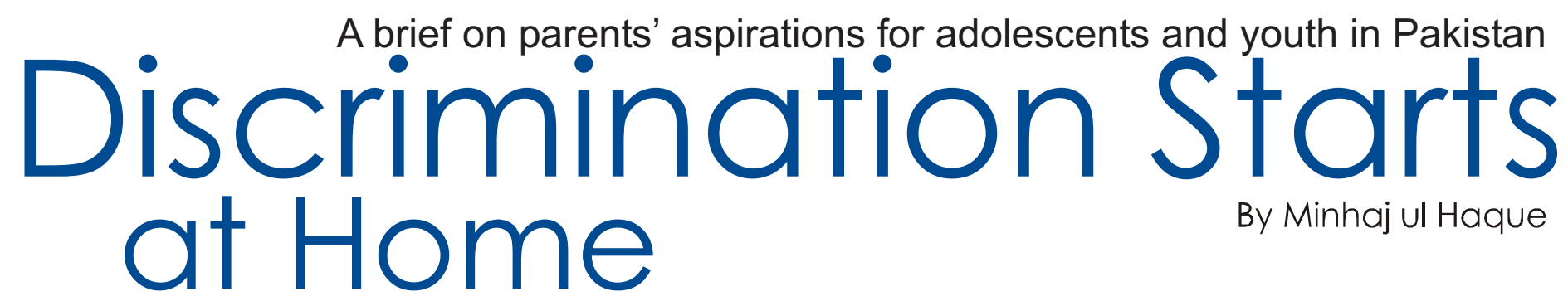

\section{Introduction}

Parents are the unchallenged stakeholders in the lives of young people in Pakistan. They play a critical role in socializing their children and passing on essential information and life skills. Therefore, as Pakistan develops policies and programs to support youth, it is essential to involve and gain the acceptance of parents. The aspirations and attitudes of parents help determine what young boys and girls do in life, how they utilize opportunities and develop the skills necessary to make a comfortable transition into adulthood. This brief is based on interviews with Pakistani parents and describes their aspirations, which are likely to influence the lives of young people.

\section{Education}

Parents play a vital role in the education of children. From the onset of school, they make decisions that affect young people's future. In this regard, parents' own literacy and educational attainment also influence the schooling of young people. Data show that a considerable proportion of parents are illiterate. The majority of mothers, over 80 percent, have never been to school.

\section{Adolescents and Youth in Pakistan}

More young people aged 15-24 live in Pakistan now than at any other time in its history - an estimated 36 million in 2004. Recognizing the dearth of information on the situation of this large group of young people in Pakistan, the Population Council undertook a nationally representative survey from October 2001 to March 2002.

The analysis presented here comes from Adolescents and Youth in Pakistan 2001-02: A Nationally Representative Survey - the largest such survey focusing on young people. The survey sought information from youth aged 15-24, responsible adults (parents, where possible) in the household where young interviewees lived, and other community members in each of the 254 communities where the survey took place. A total of 6,585 households were visited and 8,074 young people were interviewed.

Level of educational attainment of parents

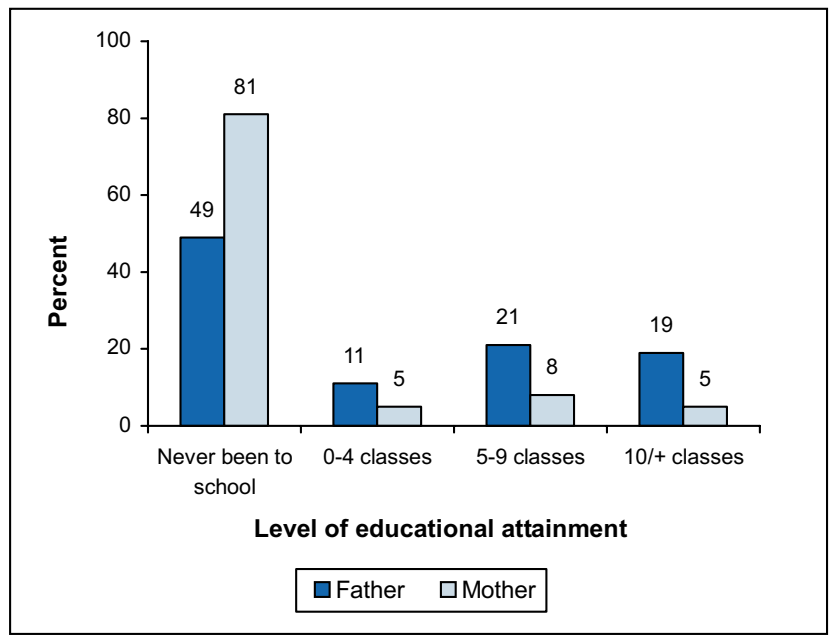


Parental literacy ${ }^{1}$ makes a profound impact on whether or not a young person goes to school and stays enrolled, or drops out. The figure below illustrates the strong positive effect of parents' literacy on their children's access to education. The influence of parental literacy is more pronounced for girls than boys, and the influence of mothers' literacy is particularly strong. Fathers' illiteracy clearly affects the education of young children. Girls are most likely to be affected; only 35 percent of girls with illiterate fathers ever attended school compared to 73 percent of boys. Ninety-seven percent of girls with literate mothers are enrolled in school, double the number with illiterate mothers.

\section{Proportion of young people who have ever} attended school by parental literacy and gender

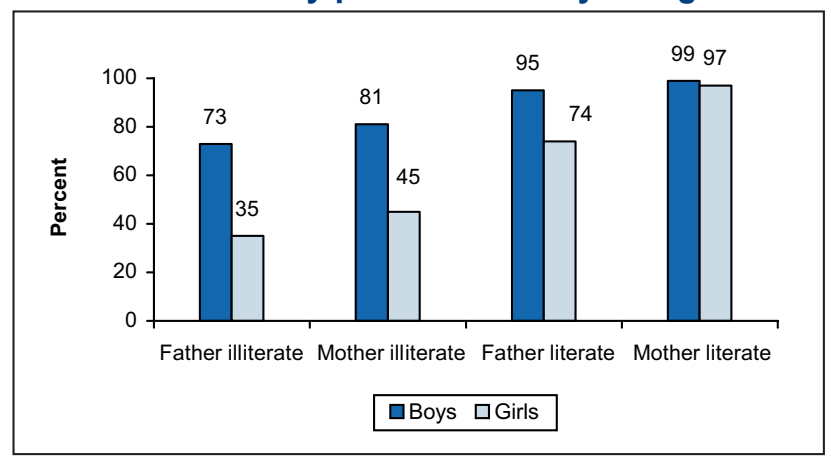

Parents expressed clear aspirations for their children's education. First, most parents want young people to attain a much higher level of schooling than they actually achieve. This is encouraging and opens the door to developing better education policies. Second, parents have different educational aspirations for their sons and daughters. Nearly half of parents feel that a boy should receive an intermediate or higher level of education (class 12 or more), whereas only one-third feels the same for girls. Urbanrural residence also makes a clear difference in parental aspirations; parents in urban areas are more likely than those in rural areas to report that an intermediate or higher level of education is desirable for young people.

Proportion of parents who prefer intermediate or higher level of schooling for young people

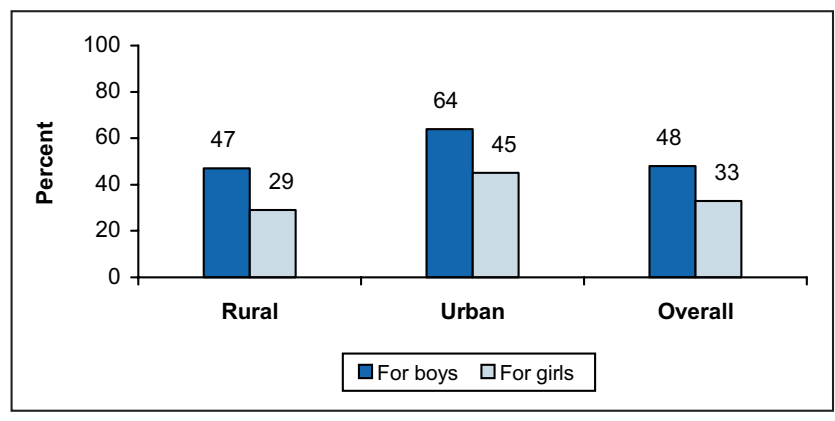

\section{Livelihood}

Attitudes and behaviors that children adopt toward work are largely a result of parents' encouragement and influence. This then affects what children think, say, and perceive about various careers. Most parents want their children to work for economic gain. More than 75 percent reported that young girls should work to supplement their families' incomes, and somewhat surprisingly, the proportion is higher in rural areas. This may reflect the poorer economic conditions of families throughout Pakistan. The percentage of those who believe that girls should work is relatively higher among mothers compared to fathers.

${ }^{1}$ Ability to read and write a simple sentence in any language. 
Percent of parents who favor that 15-24 year old girls should work for economic gain

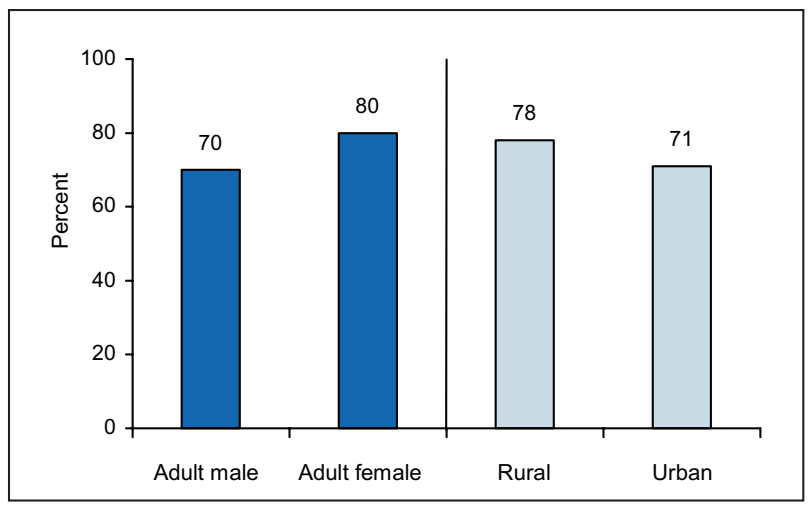

Reliance on the government sector for jobs is very strong in Pakistan. However, there are notable differences in what parents consider "good jobs" for girls and boys. For most parents, the government sector offers the most attractive jobs for boys. Teaching emerged as the most preferred occupation for girls. The top choices remain the same across socioeconomic groups. Parents in the poorest households consider farm labor as the second best option for economic activity.

Parental preferences regarding occupations for young boys and girls

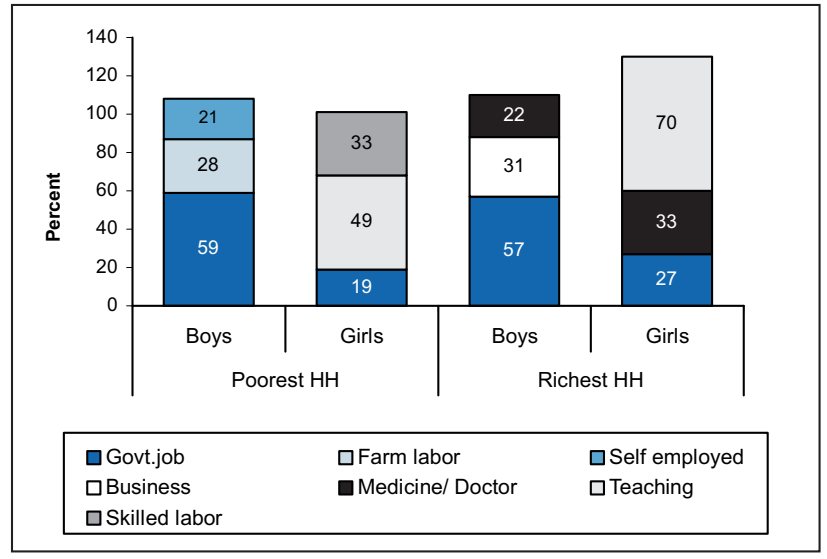

* Percentages exceed 100 due to multiple responses.

\section{Marriage}

Age at marriage has important implications for girls' health and also for population growth.
Parents were asked about the ideal age of marriage for both boys and girls. Overall, the ideal age stated was 22 for boys and 18 for girls. Mothers want young people to marry one year later than do fathers ( 23 vs. 22 for boys and 19 vs. 18 for girls, respectively). Interestingly, parents' perception about the ideal age of marriage is much lower than the actual age that young people marry in Pakistan. This implies that adolescents will continue to face pressures regarding early marriage from parents.

\section{Opinion of parents about ideal age to marry, by} gender

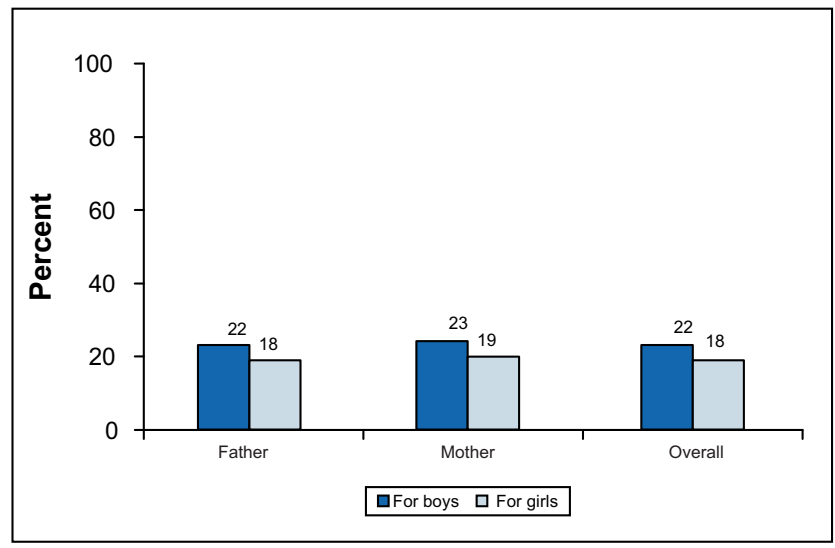

\section{Mobility}

Mobility of young boys and girls outside the home is a major concern of parents in Pakistan. Therefore, they place certain restrictions on the mobility of young people and express concerns regarding the consequences of unaccompanied mobility. Their fears are stronger for girls. Young girls carry the responsibility of family reputation and therefore their mobility is guarded closely to avoid any fallout that may bring disrespect to the family.

Boys and girls in Pakistan do not enjoy the 
same degree of freedom of movement. When parents were asked whether or not a 15-year-old boy or girl can go alone to certain places outside the home, responses varied by gender. The majority of parents consider it acceptable for boys to visit places/ persons nearby their homes, including shops, friends or health outlets. In contrast, considerably lower proportions of parents think the same for girls. For example, only 19 percent of parents consider it acceptable for girls to go alone even to visit friends, reflecting their limited options to participate in social networks.

\section{Proportion of parents who report a 15-year-old} boy or girl can go alone to selected places

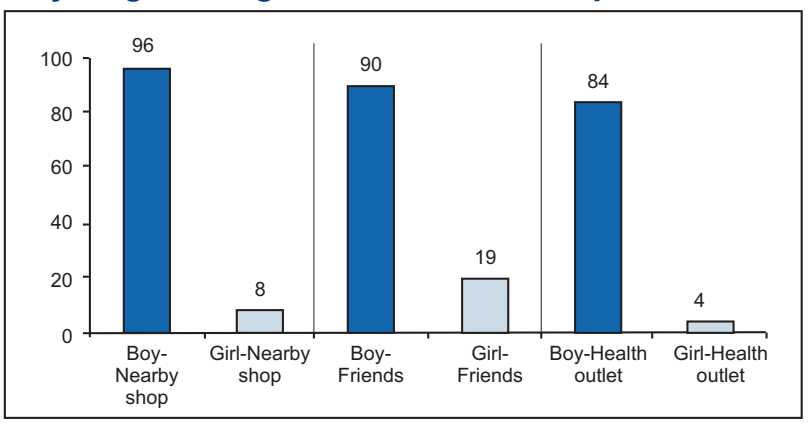

Those who say they do not allow young girls to go out on their own echo some serious concerns about the mobility of boys as well.

There is considerable concern of parents regarding street harassment that girls may face when they go outside. They also have apprehensions about young boys who are seen to be prone to bad company and drugs, and are therefore, watched attentively. The main concern of parents for boys is about undesirable behavior that young boys might adopt outside the home through keeping dangerous company.
Unsafe places young people are not allowed to go to and parental concerns

Places where young people are not allowed to go:

\begin{tabular}{|c|c|}
\hline For Girls & For Boys \\
\hline $\begin{array}{ll}\text { - } & \text { Shops/market } \\
\text { - } & \text { Other village/ } \\
\text { mohallah } \\
\text { - } & \text { Cinema }\end{array}$ & $\begin{array}{ll}\text { - } & \text { Cinema } \\
\text { - } & \text { Hotel/ restaurant } \\
\text { - } & \text { Other } \\
& \text { village/mohallah } \\
\text { - } & \text { Open/secluded } \\
& \text { places } \\
\text { - } & \text { Video game shops }\end{array}$ \\
\hline
\end{tabular}

Reasons parents report for considering certain places unsafe:

\begin{tabular}{|c|c|}
\hline For Girls & For Boys \\
\hline $\begin{array}{ll}\text { - } & \text { Family reputation } \\
\text { - } & \text { Street harassment } \\
\text { - } & \text { Personal reputation } \\
\text { - } & \text { Family } \\
& \text { opposition/tradition }\end{array}$ & $\begin{array}{ll}\text { - } & \text { Bad company } \\
\text { - } & \text { Drug addiction } \\
\text { - } & \text { Immoral activities } \\
\text { - } & \text { Personal/family } \\
& \text { reputation } \\
\text { - } & \text { Physical harm }\end{array}$ \\
\hline
\end{tabular}

\section{Ability of youth to make decisions}

Parents in Pakistan usually control all important life events of adolescents, from deciding whether or not a child goes to school, or goes to work, to making decisions regarding marriage. Parents were asked about the decision-making ability of young people regarding major life events. A clear pattern emerged by gender, as parents consider boys to have greater ability than girls to make decisions about their education, work and marriage. Parents in lower socioeconomic strata give greater liberty to boys and consider them capable enough to make important decisions about their life. Slightly fewer than half of the parents think boys can decide about their marriages, while only 18 percent feel the same way for girls. 
Proportions of parents who think young people can decide/ have right to make decisions (of education, work, and marriage)

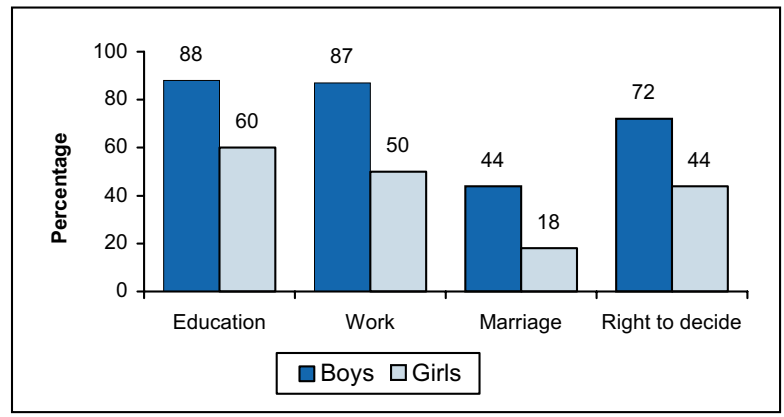

Many parents in Balochistan and NWFP do not accept the ability of a girl to make decisions about education and work. Poverty affects girls more than boys and plays a restrictive role on parents' views about girls' abilities. Overall richer parents are more likely to grant the ability and rights of young people to make important decisions.

\section{Conclusions}

Parents emerge as primary stakeholders in the lives of adolescents. It is, therefore, necessary to first understand their concerns and then to incorporate their views into youth policies and programs. Programs will definitely benefit if parents are brought into the picture with their concerns.

An important area of intervention is youth's ability to make decisions. Parents have greater confidence in boys to take decisions on important life matters as compared to girls. Many parents feel that young people have the right to make decisions; however, they are not sure about their capability to do so.
Since parents place strong concerns for their girls in every sphere of their lives, they face many disadvantages. These data make clear that gender discrimination starts at home. This has implications for how to develop interventions to help girls reach their full potential. Since girls are not expected or permitted to move outside home, they face much more resistance than boys in efforts to expand their life options. Furthermore, there was much more variation in parents' attitudes toward girls than boys across parents from different strata.

Parental views on the ability and rights of young people to make major decisions

\begin{tabular}{|c|c|c|c|c|c|c|c|c|}
\hline & \multicolumn{2}{|c|}{ Education } & \multicolumn{2}{|l|}{ Work } & \multicolumn{2}{|c|}{ Marriage } & \multicolumn{2}{|c|}{$\begin{array}{l}\text { Right to make } \\
\text { decision }\end{array}$} \\
\hline & Boys & Girls & Boys & Girls & Boys & Girls & Boys & Girls \\
\hline \multicolumn{9}{|l|}{$\begin{array}{l}\text { Socioeconomic } \\
\text { status }\end{array}$} \\
\hline Low & 83 & 48 & 86 & 44 & 43 & 16 & 67 & 35 \\
\hline Low-mid & 87 & 57 & 87 & 52 & 45 & 18 & 73 & 43 \\
\hline High-mid & 90 & 63 & 88 & 52 & 44 & 17 & 74 & 44 \\
\hline High & 90 & 71 & 87 & 54 & 43 & 22 & 76 & 55 \\
\hline \multicolumn{9}{|l|}{ Province } \\
\hline Punjab & 91 & 68 & 90 & 57 & 42 & 19 & 75 & 48 \\
\hline Sindh & 87 & 52 & 86 & 46 & 45 & 17 & 67 & 37 \\
\hline NWFP & 74 & 43 & 75 & 34 & 46 & 16 & 65 & 37 \\
\hline Balochistan & 84 & 43 & 82 & 34 & 52 & 13 & 76 & 45 \\
\hline
\end{tabular}

There is a very high degree of parental control on girls' mobility. Though parents have high aspirations and continue to support education and work for young girls, they place important barriers on their mobility, which ultimately hampers their education and the opportunities to obtain life skills. Parents support female work for economic gains for the family. This is an area to consider for policy interventions. Programs that enhance livelihood skills of young people will encourage parents to allow their daughters to work.

Since parents act as gatekeepers in the lives of young people, the AYP data highlight key areas that programs need to address first through advocacy with parents. 


\section{Acknowledgments}

The publication of this brief is made possible through a grant from the Population Reference Bureau (PRB). Dr. Nancy V. Yinger, Director of International Programs, PRB, provided the inspiration for making the brief and aided the author in deciding on the main theme of the brief. The author is grateful to Dr. Zeba Sathar, Country Director, Population Council, for her essential guidance and timely help on the subject matter. The credit for layout and design goes to Mehmood Asghar. Pamela Ledbetter edited the brief.

The analysis presented here comes from Adolescents and Youth in Pakistan 2001-02: A Nationally Representative Survey. Rockefeller Foundation-USA, Department for International Development-UK, and UNICEF-Pakistan donated precious funds for the survey. UNFPA donated some funds for the completion of the project. 


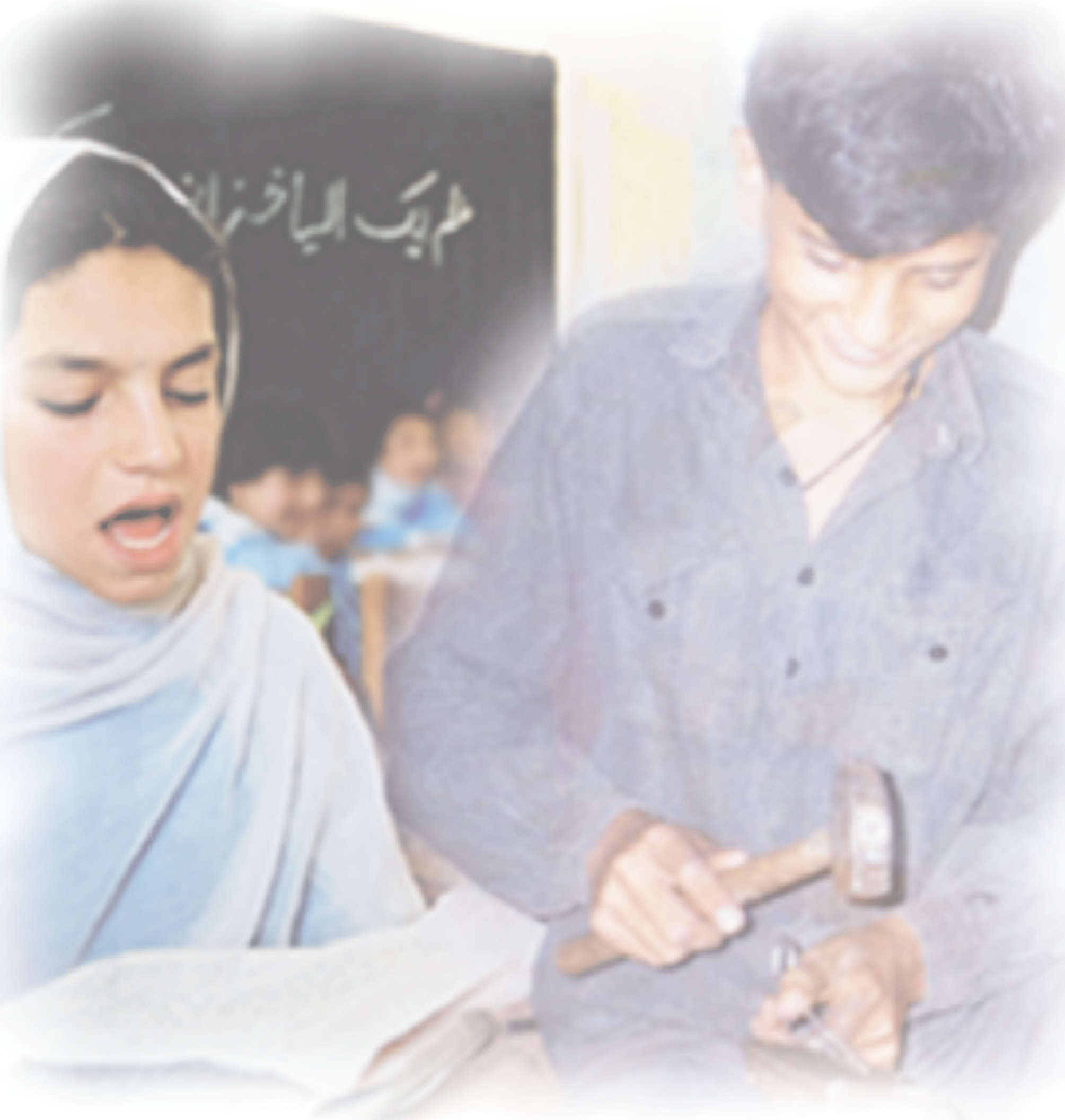




\section{Population Council}

The Population Council, an international, nonprofit, nongovernmental organization established in 1952, seeks to improve the well-being and reproductive health of current and future generations around the world and to help achieve a humane, equitable, and sustainable balance between people and resources.

The Council analyzes population issues and trends; conducts research in the reproductive sciences; develops new contraceptives; works with public and private agencies to improve the quality and outreach of family planning and reproductive health services; helps governments design and implement effective population policies; communicates the results of research in the population field to diverse audiences; and helps strengthen professional resources in developing countries through collaborative research and programs, technical exchanges, awards, and fellowships.

\footnotetext{
Population Council

\#7, St. 62, F-6/3

Islamabad, Pakistan

Ph: (92-51) 2277439

Fax: (92-51) 2821401

Email: info@pcpak.org
} 